\section{Effect of a mutation in Raffinose Synthase 2 (GmRS2) on soybean quality traits}

\author{
Luiz Cláudio Costa Silva ${ }^{1^{*}}$, Larissa Martins Mota ${ }^{2}$, Letícia \\ Assis Barony Vasconcelos Fonseca², Rafael Delmond Bueno², \\ Newton Deniz Piovesan ${ }^{2}$, Elizabeth Pacheco Batista Fontes ${ }^{3}$ \\ and Maximiller Dal-Bianco ${ }^{2}$
}

\begin{abstract}
The presence of stachyose and raffinose is considered an antinutritional factor for humans and monogastric animals, leading to limitations on soybean consumption as a protein source. In the present study, the effect of a mutation in the raffinose synthase 2 gene was measured on soybean quality traits. We used an $F_{2}$ population with 168 soybean individuals developed by crossing four soybean lines and evaluated oil, protein, sucrose, raffinose, stachyose and fatty acid contents and their relationships. The mutation explained $69.61 \%, 51.81 \%$ and $31.96 \%$ of stachyose, raffinose and sucrose variation, respectively, and we were able to produce soybean with average stachyose of $0.18 \%$. The low coefficients of determination for protein and oil indicate that the mutation can be used to increase sucrose and reduce raffinose and stachyose content without major changes in oil and protein.
\end{abstract}

Keywords: Stachyose, sucrose, specialty soybeans, soybean breeding, RFO.

\section{INTRODUCTION}

Soybean (Glycine max (L.) Merrill) is one of the most important crops in the world, and is among the main commodities in Brazilian agribusiness. Brazil is the second largest producer, producing 119.281 million tons of grain for the $2017 / 2018$ harvest, about one-third of global production (CONAB 2019). Over the years, the demand for special soybeans has been increasing due to the direct use of the grain, or in the production of derivatives, such as textured protein, tofu, soymilk, natto and edamame (Wang et al. 2014, Matei et al. 2017, Jiang et al. 2018).

Oligosaccharide content is one of the factors responsible for soybean quality. Sucrose is the only oligosaccharide useful for monogastric digestion (Yang et al. 2014), and its content in the grain is a critical factor to produce soybean derivatives (Sato et al. 2014, Wang et al. 2014). In addition, sucrose is probably the main factor influencing the flavor of vegetable soybean (Li et al. 2012).

The presence of the raffinose family of oligosaccharides (RFOs) in soybean, which includes raffinose and stachyose $\alpha$-galactosides, is considered an antinutritional factor because humans and monogastric animals do not have $\alpha$-galactosidase, the enzyme responsible for hydrolyzed RFOs (Yang et al. 2014, Matei et al. 2017). RFO consumption by organisms without $\alpha$-galactosidase can
Crop Breeding and Applied Biotechnology 19: 62-69, 2019 Brazilian Society of Plant Breeding. Printed in Brazil http://dx.doi.org/10.1590/198470332019v19n1a09
. 
cause organic dysfunctions such as diarrhea, nausea and flatulence (Liener 1994, Reddy et al. 2016, Matei et al. 2017). Stachyose is the second most significant soluble sugar in soybean, usually ranging from 1.4-4.1\% (Hymowitz et al. 1972, Zeng et al. 2015), and leads to limitations on soybean consumption as a protein source. The reduction of stachyose and raffinose will increase the metabolized energy and will promote a decrease in the undesirable effects of RFO consumption (Suarez et al. 1999, Parsons et al. 2000, Dierking and Bilyeu 2008).

The literature describes several procedures to reduce or eliminate stachyose content in soybean grains and byproducts. These include imbibition and germination (Kim et al. 1973); fermentation processes (Mital and Steinkraus 1975); oligosaccharide extraction in water (Ku et al. 1976); ultrafiltration of water-soluble soy extract (Omosaiye et al. 1978); oligosaccharide extraction with ethanol from soybean meal (Leske et al. 1991); and use of plant and microbial $\alpha$-galactosidase (Guimarães et al. 2001), among others. However, the production of low stachyose soybean varieties, associated with high levels of sucrose and protein, is an interesting alternative to improve the nutritional quality of soybeans (Sato et al. 2014), since these varieties will reduce the time and costs for process the grain and its derivatives.

Raffinose and stachyose biosynthesis is mediated by raffinose synthase enzymes, which perform a transfer of galactosyl residues from galactinol to sucrose (Dierking and Bilyeu 2008, Qiu et al. 2015, Bilyeu and Wiebold 2016). Skoneczka et al. (2009) characterized a three base pair deletion in raffinose synthase 2 gene (GmRS2-Glyma.06G179200) on PI200508 accession (high sucrose and low stachyose content). This mutation was analyzed in two $\mathrm{F}_{2}$ populations derived from PI200508 and explained $88-94 \%$ and $76 \%$ of stachyose and sucrose content in the grain, respectively. Neus et al. (2005) reported that seed vigor is not affected in lineages with low RFO content derived from PI200508, and there are no significant differences in seed quality characteristics such as emergence in the field, seed yield, maturity, height and fatty acid contents. These characteristics are important for soybean nutritional quality (Yang et al. 2014), making PI200508 a good allele donor for low RFO content.

Correlations between grain quality traits have been investigated by many researchers (Hymowitz et al. 1972, Hartwig et al. 1997, Wilcox and Shibles 2001, Jiang et al. 2018). The production of sucrose, raffinose and stachyose are in the same metabolic pathway (Dierking and Bilyeu 2008, Bilyeu and Wiebold 2016), and an increase in sucrose content by inhibiting RFO synthesis is expected without a decrease in protein content (Sato et al. 2014). In the present study, we used a population derived by crossing four soybean lines, segregating for several grain quality characteristics, to validate a new molecular marker based on the mutation found in the lineage PI200508, and to study the effect of this mutation on soybean quality traits.

\section{MATERIAL AND METHODS}

\section{Plant material and population development}

The present study developed an $\mathrm{F}_{2}$ population with 168 individuals by crossing PI603452, PI283327, PI200508 and NA5909. PI200508 has a mutation associated with low stachyose levels (Skoneczka et al. 2009). Accessions PI603452 and PI283327 have mutations in GmFAD2-1A and GmFAD2-1B genes, respectively, and when combined can produce soybean with more than $80 \%$ oleic acid (Pham et al. 2011, Pham et al. 2012). The cultivar NA5909 (Nideira Seeds) is a high agronomic performance variety. The population was developed using the following steps: PI603452 was crossed with PI2883327, and the resultant $F_{1}$ was crossed with PI200508. This new $F_{1}$ was crossed with the NA5909 variety. These $F_{1}$ plants were genotyped for the mutation in the GmRS2 gene from PI200508 (see the next section, Genotyping Analysis), and heterozygous plants were used to produce the $F_{2}$ population.

The varieties UFVTN105AP (high protein - BIOAGRO/UFV), CS303TNKCA (low linolenic, middle oil - BIOAGRO/UFV) and Tucunaré (good agronomic traits - Mato Grosso Foundation) were used as additional controls. All the crosses and the $F_{2}$ population were conducted in a greenhouse at the Universidade Federal de Viçosa, in Viçosa, Minas Gerais. $F_{2}$ seeds were planted in June and harvested in October 2015. $\mathrm{F}_{2: 3}$ seeds were used for phenotypic analysis.

\section{Genotyping Analysis}

Leaf samples from PI603452, PI283327, PI200508, NA5909, $\mathrm{F}_{1}$ and $\mathrm{F}_{2}$ plants were harvested at V2 stage (Fehr and Caviness 1977), frozen in liquid nitrogen and stored in a freezer at $-80^{\circ} \mathrm{C}$. Genomic DNA was extracted using the methodology 
proposed by Doyle and Doyle (1990). The DNA concentration was determined using a NanoDrop spectrophotometer (NanoDrop Technologies, Wilmington, DE) and the quality was checked by $0.8 \%$ agarose gel electrophoresis.

Primers developed by Skoneczka et al. (2009) (Forward 5'-GGACTTGAAGGAACAGTTTAGG-3', and Reverse 5'-CGTTACTGACGATCTTATCCAC-3') were evaluated to check the suitability for High Resolution Melt (HRM) genotyping methodology (Liew et al. 2004, Simko 2016). Subsequently, the same primers were used to sequence the mutation region of GmRS2 gene in the four parents used in this study. After the sequencing, a new set of HRM primers was designed (Forward 5'-GTGGAGCAGGTGTATGTG-3', and Reverse 5'-GTCTGACCCCACCCCAATAC-3'). The $F_{2}$ population genotyping was performed in RotorGene-Q (QIAGEN), and the reaction was carried out using $30 \mathrm{ng}$ of DNA, $0.7 \mu \mathrm{M}$ of each primer, and $5 \mu \mathrm{L}$ of Type-it HRM 2X PCR kit (QIAGEN), in a total volume of $10 \mu \mathrm{L}$. DNAs from PI200508, NA5909 and one $\mathrm{F}_{1}$ plant were used as standards for mutant, wild and heterozygous genotypes, respectively. Each sample was made in duplicate, and the PCR was performed under the following conditions: $94{ }^{\circ} \mathrm{C}$ for 10 minutes; 40 cycles started at $94{ }^{\circ} \mathrm{C}$ for 20 seconds, $54{ }^{\circ} \mathrm{C}$ for 20 seconds, and $72{ }^{\circ} \mathrm{C}$ for 30 seconds. Finally, the amplification products were subjected to a temperature gradient of 60 to $90^{\circ} \mathrm{C}$, reading fluorescence each $0.1^{\circ} \mathrm{C}$ to determine the melting curves.

\section{Phenotyping analyses}

Moisture, protein, and oil contents were determined using near-infrared (NIR) spectroscopy (FT-NIR analyzer, Thermo Scientific, model Antaris II) using 20-30 crushed seeds. The extraction of sucrose, raffinose and stachyose oligosaccharides was performed as described by Teixeira et al. (2012), and the extract was analyzed by high performance liquid chromatography (HPLC) in a Shimadzu Prominence chromatograph using acetonitrile as a mobile phase. Lipids were extracted as described by Gesteira et al. (2003), and analyzed in a Shimadzu GC-2010 Plus chromatograph.

\section{Statistical analysis}

To verify the segregation of GmRS2 gene mutation in $\mathrm{F}_{2}$ population, the Chi-Square test was used. Descriptive statistics (mean, maximum, minimum, amplitude, variance and standard deviation) were calculated for each mutation genotype and for each trait. The Pearson Correlation Coefficient was calculated for each pair of characteristics, and its significance was assessed by the t-test. To estimate the effect of the GmRS2 gene on the evaluated characteristics, linear regression was performed. The coefficient of regression significance was verified using t-test, and the linear model adjustment for each regression was measured by the coefficient of determination. Graphs were constructed showing the distribution of sucrose, raffinose and stachyose content for mutant, wild and heterozygous individuals, showing their means and coefficient of determination.

\section{RESULTS AND DISCUSSION}

\section{Population development and genotyping method}

The population used in this study was developed by crossing four soybean lines as described in the methodology. We used the primers designed by Skoneczka et al. (2009) for genotyping, using HRM methodology, and to select individuals from $F_{2}$ population containing the mutation in the GmRS2 gene (Glyma.06G179200). However, the marker did not show Mendelian segregation in the evaluated population, probably due to some unidentified mutation in the amplified region of the accesses used. To evaluate this hypothesis, we amplified and sequenced the fragments from PI200508, PI283327, PI603452, and NA5909 using the same primers developed by Skoneczka et al. (2009) and generated fragments ranging from 182 to $185 \mathrm{bp}$. We re-identified the $3 \mathrm{bp}$ deletion in PI200508 accession, however, we found a silent mutation at position 25 in PI603452 accession (C>T) (Figure 1A), used for the development of soybean with more than 80\% oleic acid (Pham et al. 2011, Pham et al. 2012). Since the High-Resolution Melt technique is sensitive to variations of a single nucleotide (Wu et al. 2008, Simko 2016), this mutation can alter the denaturation curve and consequently the correct identification of genotypes derived from PI603452. Therefore, we redesigned the molecular diagnosis to amplify a $55 \mathrm{bp}$ fragment that does not include the PI603452 mutation region (Figure 1A and 1B). A total of $168 \mathrm{~F}_{2}$ plants were genotyped and this new marker behaves as expected for Mendelian segregation. We found 42 mutant, 78 heterozygous and 48 wild-type plants, obtaining a chi-square of $1.29(p=0.53)$. 


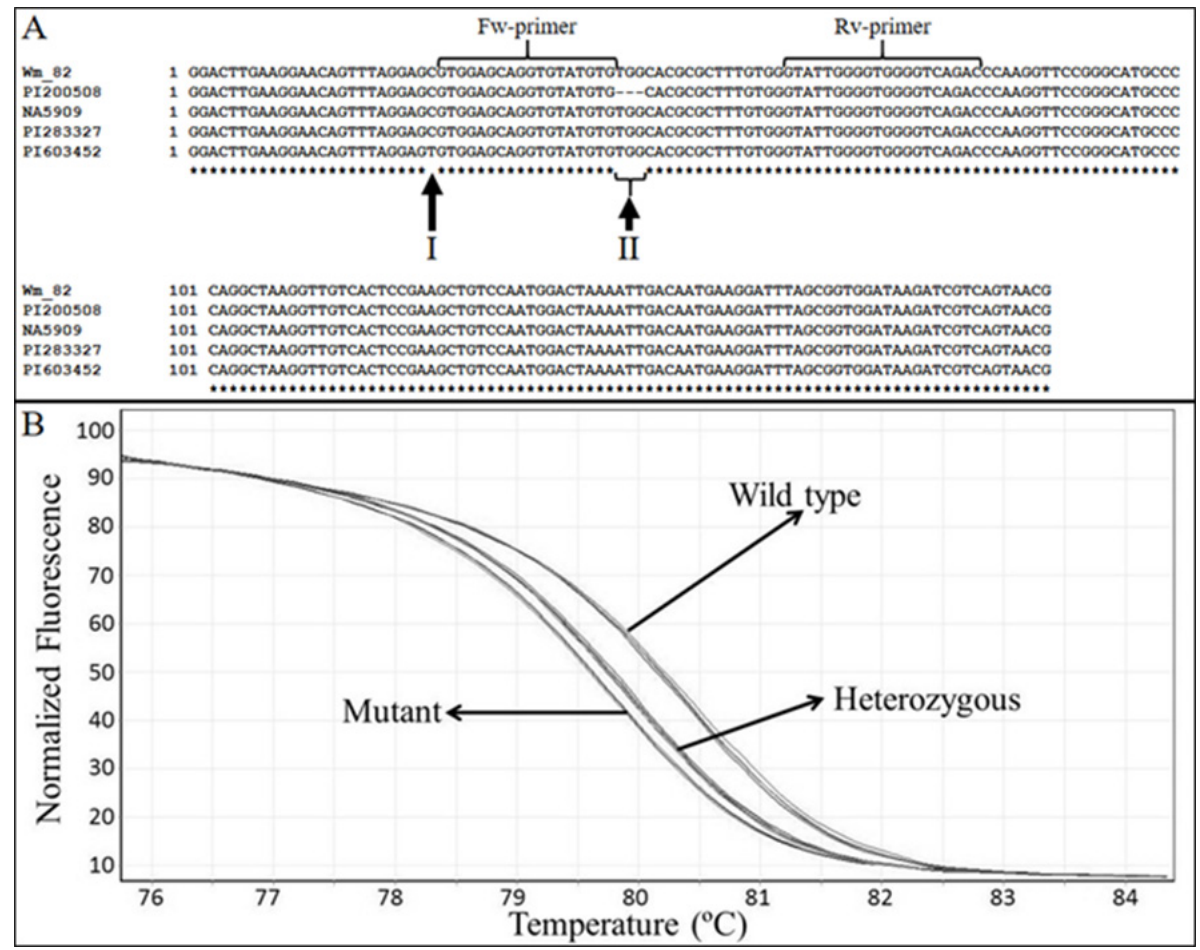

Figure 1. A. Alignment of a GmRS2 fragment amplified by the primers described by Skoneczka et al. (2009) for all parents of the segregating population and reference genome (Wm_82). The new mutation identified in PI603452 (I), the previously identified mutation in PI200508 (II) and the position of the new set of primers for HRM are shown. B. High resolution melt marker assay. The genotype method was developed based on a 3-bp deletion in the GmRS2 soybean gene found in PI200508 as described in the methodology. The normalized melt curves of mutant, heterozygous and wild type genotypes are shown.

\section{Descriptive statistics}

The population used in this study was phenotyped, the data were statistically evaluated and the variability for all characteristics analyzed was determined (Table 1). The stachyose content ranged from $0.04-0.55 \%$ for mutants and $1.11-2.96 \%$ for wild type individuals, with averages of $0.18 \%$ and $2.08 \%$, respectively. Skoneczka et al. (2009) found higher levels of stachyose, ranging from $0.56-1.47 \%$ for mutant and $2.58-5.63 \%$ for wild type using two $F_{2}$ populations derived from PI200508 and the accessions PI87013 or PI243545. The sucrose and raffinose contents ranged from 1.33$7.07 \%$ and $0.02-0.84 \%$, respectively. A broad range of variation was found in protein and oil contents $33.00-47.82 \%$ and 12.75-25.51\%, respectively, with maximum values close to those found in UFVTN105AP (high protein) and CS303TNKCA (middle oil) control varieties. The fatty acid contents ranged between $6.67-17.32 \%$ for palmitic acid, $2.38-5.45 \%$ for stearic acid, 17.11-82.17\% for oleic acid, 4.01-60.99\% for linoleic acid, and 3.70-10.96\% for linolenic acid. The results showed that maximum and minimum values for all characteristics exceeded the parental values, indicating the occurrence of transgressive segregation. This phenomenon occurs when the parental individuals are divergent for the trait and they do not have the extreme genotypic combinations (Grant 1964), and was observed in other studies with soybean populations segregated by protein content (Hyten et al. 2004), grain yield and weight (Mansur et al. 1993), sucrose and oligosaccharide content (Kim et al. 2006), and oleic (Pham et al. 2011, Bueno et al. 2018) and linoleic acid contents (Pham et al. 2011). Progenies derived from divergent crosses are expected to show a broad spectrum of genetic variability, providing an increase in the number of transgressive segregating individuals (Tyagi and Khan 2010, Mughal et al. 2015).

\section{Linear regression and relations between seed quality features}

Linear regression analysis showed a significant association between GmRS2 mutation and sucrose, raffinose, stachyose, protein and oil contents (Table 2). Graphs were designed using the distribution of sucrose, raffinose or stachyose contents 
Table 1. Descriptive statistics of seed quality features. The table shows the values of $F_{2}$ soybean segregating population generated by crossing four soybean lines, parents and three additional witnesses

\begin{tabular}{|c|c|c|c|c|c|c|c|c|c|c|c|c|}
\hline Statistics & & Pro & Oil & Suc & Raf & Sta & Oli & Pal & Ste & Ole & Lol & Lin \\
\hline \multicolumn{13}{|c|}{ Witnesses and parentals } \\
\hline & NA5909 & 37.53 & 24.42 & 1.89 & 0.51 & 1.38 & 3.42 & 11.91 & 4.65 & 21.02 & 55.77 & 6.65 \\
\hline & PI200508 & 41.98 & 16.95 & 4.84 & 0.11 & 0.30 & 5.25 & 9.79 & 2.69 & 41.91 & 39.02 & 6.60 \\
\hline & PI283327 & 42.85 & 17.46 & 3.02 & 0.27 & 1.76 & 5.05 & 10.11 & 5.09 & 28.14 & 45.91 & 10.74 \\
\hline & PI603452 & 41.35 & 18.29 & 3.18 & 0.19 & 1.69 & 5.06 & 10.85 & 3.61 & 33.86 & 43.16 & 8.53 \\
\hline & UFVTN105AP & 48.09 & 17.62 & 1.81 & 0.43 & 1.61 & 3.85 & 11.25 & 3.81 & 27.10 & 52.76 & 5.08 \\
\hline \multicolumn{13}{|c|}{$F_{2}$ Population } \\
\hline \multirow{4}{*}{ Average } & $\mathrm{F}_{2}$ population & 40.66 & 19.74 & 3.84 & 0.27 & 1.34 & 5.45 & 10.64 & 3.61 & 29.66 & 47.99 & 8.15 \\
\hline & Mutant & 39.21 & 20.80 & 5.07 & 0.11 & 0.18 & 5.36 & 10.69 & 3.63 & 30.22 & 47.63 & 7.98 \\
\hline & Heterozygous & 41.22 & 19.28 & 3.62 & 0.25 & 1.51 & 5.38 & 10.73 & 3.61 & 29.25 & 48.11 & 8.30 \\
\hline & Wild type & 41.02 & 19.55 & 3.11 & 0.45 & 2.08 & 5.64 & 10.43 & 3.57 & 29.84 & 48.12 & 8.06 \\
\hline Minimum & Wild type & 36.06 & 14.35 & 1.33 & 0.23 & 1.11 & 2.79 & 7.39 & 2.74 & 17.11 & 4.22 & 3.70 \\
\hline \multirow{4}{*}{ Maximum } & $\mathrm{F}_{2}$ population & 47.82 & 25.51 & 7.07 & 0.84 & 3.11 & 10.16 & 17.32 & 5.45 & 82.17 & 60.99 & 10.96 \\
\hline & Mutant & 45.84 & 25.37 & 7.07 & 0.22 & 0.55 & 7.30 & 13.88 & 5.26 & 82.17 & 60.99 & 10.08 \\
\hline & Heterozygous & 47.57 & 24.33 & 6.21 & 0.61 & 3.11 & 8.41 & 17.32 & 5.45 & 81.42 & 60.17 & 10.96 \\
\hline & Wild type & 47.82 & 25.51 & 7.01 & 0.84 & 2.96 & 10.16 & 14.57 & 4.76 & 81.78 & 57.78 & 10.34 \\
\hline \multirow{4}{*}{ Spread } & $\mathrm{F}_{2}$ population & 14.82 & 12.76 & 5.74 & 0.82 & 3.07 & 7.70 & 10.65 & 3.07 & 65.06 & 56.98 & 7.26 \\
\hline & Mutant & 12.84 & 9.92 & 4.58 & 0.20 & 0.51 & 4.64 & 7.15 & 2.88 & 62.81 & 56.67 & 6.14 \\
\hline & Heterozygous & 12.87 & 11.58 & 4.69 & 0.59 & 2.34 & 5.95 & 10.65 & 2.87 & 64.18 & 56.16 & 6.25 \\
\hline & Wild type & 11.76 & 11.16 & 5.68 & 0.61 & 1.85 & 7.37 & 7.18 & 2.02 & 64.67 & 53.56 & 6.64 \\
\hline Standard Deviation & $F_{2}$ population & 3.16 & 2.73 & 1.25 & 0.18 & 0.82 & 1.22 & 1.32 & 0.54 & 10.54 & 9.46 & 1.09 \\
\hline
\end{tabular}

Pro: Protein; Suc: Sucrose; Raf: Raffinose; Sta: Stachyose; Oli: Oligosaccharides (Sucrose + raffinose + stachyose); Pal: palmitic acid; Ste: Stearic acid; Ole: Oleic acid; Lol: Linoleic acid; Lin: Linolenic acid.

and the genotypes identified (Figure 2). The mutation explained $69.61 \%, 51.81 \%$ and $31.96 \%$ of the variation in stachyose, raffinose and sucrose content, respectively. Skoneczka et al. (2009) found different coefficients of determination values, and this can be explained in part by the differences in experimental location and by the population used. We developed a population using four divergent parents, which may lead to an increase in segregation, generating greater genetic variability (Hanson 1959, Alliprandini and Vello 2004).

We found an association between the mutation in GmRS2 gene and protein and oil contents, but the coefficients of determination were low ( $4.1 \%$ for protein and $2.6 \%$ for oil), indicating that the mutation can be used to increase sucrose and reduce raffinose and stachyose contents, without major changes in oil and protein, as suggested by Sato et al. (2014). Additionally, no association was found between the mutation and the amount of oligosaccharides (sum of
Table 2. Linear regression of soybean seed quality features $\mathrm{x}$ GmRS2 genotype

\begin{tabular}{lccc}
\hline Feature & $\mathbf{F}$ value & $\boldsymbol{\beta}_{1}$ & $\mathbf{R}^{\mathbf{2}}(\%)$ \\
\hline Protein & $7.1^{* *}$ & $0.87^{* *}$ & 4.10 \\
Oil & $4.36^{*}$ & $-0.60^{* *}$ & 2.56 \\
Sucrose & $77.97^{* *}$ & $-0.97^{* *}$ & 31.96 \\
Raffinose & $178.5^{* *}$ & $0.17^{* *}$ & 51.81 \\
Stachyose & $380.2^{* *}$ & $0.93^{* *}$ & 69.61 \\
Oligosaccharides & 1.19 & 0.14 & 0.71 \\
Palmitic & 0.99 & -0.14 & 0.59 \\
Stearic & 0.28 & -0.03 & 0.17 \\
Oleic & 0.02 & -0.17 & 0.01 \\
Linoleic & 0.06 & 0.24 & 0.03 \\
Linolenic & 0.07 & 0.03 & 0.04 \\
\hline
\end{tabular}

$* p \leq 0.05 ; * * \leq 0.01$; Oligosaccharides: Sucrose + raffinose + stachyose. 
sucrose, raffinose and stachyose contents), indicating that the variation in oligosaccharides content is mainly due to the reduced conversion of sucrose into raffinose (Skoneczka et al. 2009, Yang et al. 2014). Regarding the composition of oil, no association was found between the mutation and palmitic, stearic, oleic, linoleic and linolenic acids, agreeing with Neus et al. (2005).

A negative correlation between protein and sucrose was found (-0.40) (Table 3), a value lower than what has been previously reported. Hartwig et al. (1997) evaluated 20 high protein and 20 high oil soybean cultivars and breeding lines and found a correlation of -0.78 between protein and sucrose. Wilcox and Shibles (2001) found a correlation of -0.66 for these two traits evaluating $F_{4: 5}, F_{4: 6}$ and $F_{4: 7}$ soybean populations derived from crossing C1834 (low protein) and CX1314-37 (high protein) lines. In another study, Jaureguy et al. (2011) evaluated the protein and sugar content of $98 \mathrm{~F}_{4: 5}$ soybean RILs derived from crossing R951705 (45.9\% of protein and $3.4 \%$ of sucrose, on average) and MFL-552 (41.7\% of protein and $4.72 \%$ of sucrose, on average), and found an average correlation of $-0.68 \%$ between these traits. Sato et al. (2014) found a correlation of -0.86 between protein and sucrose in a study with four soybean populations derived from different crosses. Sucrose is directly involved in protein biosynthesis (Li et al. 2012), and the negative correlation between sucrose and protein is probably due to the competition for ATP and carbon skeleton requirement for each pathway (Paul and Foyer 2001). Carbohydrate accumulation is an important factor involved in protein production during the grain filling period, and for this reason, the carbon and nitrogen metabolism are not completely independent (Li et al. 2012). As discussed earlier, this smaller negative correlation in our data may be due to the segregation of other genes with effect on both characteristics, given that the effect of the mutation in the GmRS2 gene is only related to the conversion of sucrose into raffinose.

Table 3. Pearson simple correlation coefficients between soybean seed quality features in a segregating population generated by crossing four soybean lines

\begin{tabular}{|c|c|c|c|c|c|c|c|c|c|c|c|}
\hline Traits & Protein & Oil & Sucrose & Raffinose & Stachyose & Oligo & Palmitic & Stearic & Oleic & Linoleic & Linolenic \\
\hline Protein & 1 & $-0.8483 * *$ & $-0.4019 * *$ & -0.0442 & 0.0099 & $-0.4120 * *$ & 0.1007 & 0.0320 & 0.0391 & -0.0940 & $0.2183^{* *}$ \\
\hline Oil & & 1 & $0.3125^{* *}$ & 0.0529 & 0.0240 & $0.3448^{* *}$ & $-0.2858 * *$ & -0.0804 & 0.0905 & -0.0043 & $-0.4010 * *$ \\
\hline Sucrose & & & 1 & $-0.2704 * *$ & $-0.4147 * *$ & $0.7091 * *$ & 0.0073 & -0.0023 & 0.0393 & -0.0036 & $-0.2320 * *$ \\
\hline Raffinose & & & & $1 b$ & $0.6465 * *$ & $0.3015^{* *}$ & -0.1041 & -0.0387 & 0.0245 & -0.0106 & -0.0541 \\
\hline Stachyose & & & & & 1 & $0.3397^{* *}$ & -0.1093 & -0.0164 & -0.0048 & 0.0205 & -0.0399 \\
\hline Oligo & & & & & & 1 & -0.0816 & -0.0193 & 0.0412 & 0.0082 & $-0.2734^{* *}$ \\
\hline Oleic & & & & & & & & & 1 & $-0.9811^{* *}$ & $-0.5806 * *$ \\
\hline Linoleic & & & & & & & & & & 1 & $0.5019 * *$ \\
\hline Linolenic & & & & & & & & & & & 1 \\
\hline
\end{tabular}

${ }^{*} \mathrm{p} \leq 0.05 ;{ }^{* *} \mathrm{p} \leq 0.01$ (t-test); Oligo = oligosaccharides (Sucrose + raffinose + stachyose). 
It is important to mention that our data showed an agreement with correlations previously reported as a negative correlation between oil and protein (Hartwig et al. 1997, Wilcox and Shibles 2001, Sato et al. 2014, Jiang et al. 2018) and a positive correlation between oil and sucrose (Hartwig et al. 1997, Sato et al. 2014). Regarding sugars, significant correlations were found between sucrose and raffinose $(-0.27)$, sucrose and stachyose $(-0.41)$ and raffinose and stachyose (0.65). Negative correlations between sucrose and raffinose (Hymowitz et al. 1972, Hartwig et al. 1997, Skoneczka et al. 2009, Jaureguy et al. 2011, Jiang et al. 2018) and between sucrose and stachyose (Hymowitz et al. 1972, Neus et al. 2005, Skoneczka et al. 2009) are commonly found in other studies. The positive correlation found between raffinose and stachyose is in agreement with results found in the literature (Hymowitz et al. 1972, Hartwig et al. 1997, Neus et al. 2005, Wang et al. 2014, Matei et al. 2017), however negative values were also observed (Skoneczka et al. 2009, Jaureguy et al. 2011, Qiu et al. 2015, Jiang et al. 2018).

Breeding programs focused on the development of special soybeans seek for adequate seed size, high levels of protein and sucrose and low levels of the oligosaccharides raffinose and stachyose (Chen 2004, Jaureguy et al. 2011). In the present study, we developed and validated a new genotyping methodology for the mutation in the GmRS2 gene (Skoneczka et al. 2009), and used it to evaluate the effect of this mutation on several grain quality characteristics. The results show that it is possible to increase sucrose and reduce stachyose and raffinose contents without major changes in other grain quality characteristics, such as oil and protein, by interrupting the conversion of sucrose into raffinose. This information is important to assist breeders to develop varieties that best suit the market for specialty soybeans.

\section{REFERENCES}

Alliprandini LF and Vello NA (2004) Heritability and correlations among traits in four-way soybean crosses. Euphytica 136: 81-91.

Bilyeu KD and Wiebold WJ (2016) Environmental stability of seed carbohydrate profiles in soybeans containing different alleles of the raffinose synthase 2 (RS2) gene. Journal of Agricultural and Food Chemistry 64: 1071-1078.

Bueno RD, God PIVG, Prata IO, Pereira PHS, Teixeira Al, Piovesan ND and Barros EG (2018) Association of candidate genes for fatty acid content in soybean by temperature-switch PCR (TSP) genotyping. Crop Breeding and Applied Biotechnology 18: 244-251.

Chen P (2004) Developing high quality identity-preserved soybean for the specialty soy food market. In Chen P (eds) Production and marketing of identity-preserved Soybean. American Soybean Association, St. Louis, p. 23-31.

CONAB - Companhia Nacional De Abastecimento (2019) Acompanhamento da safra brasileira de grãos v.6 - Safra 2018/2019, n.5 - Quinto levantamento. CONAB, Brasília, 122p.

Dierking EC and Bilyeu KD (2008) Association of a soybean raffinose synthase gene with low raffinose and stachyose seed phenotype. The Plant Genome 1: 135-145.

Doyle JJ and Doyle JL (1990) Isolation of plant DNA from fresh tissue. Focus 12: 13-15.

Fehr WE and Caviness CE (1977) Stages of soybean development. Special Report: Agriculture and Home Economics Experiment Station. lowa State University, lowa, 13p.

Gesteira AS, Schuster I, José IC, Piovesan ND, Viana JMS, Barros EG and Moreira MA (2003) Biometrical analyses of linolenic acid content of soybean seeds. Genetics and Molecular Biology 26: 65-68.

Grant V (1964) The architecture of the germplasm. John Wiley and Sons,
New York, 212p.

Guimarães VM, Rezendo ST, Moreira MA, Barros EG and Felix CR (2001) Characterization of $\alpha$-galactosidases from germinating soybean seed and their use for hydrolysis of oligosaccharides. Phytochemistry 58: 67-73.

Hanson WD (1959) The breakup of initial linkage blocks under selected mating systems. Genetics 44: 857-868.

Hartwig EE, Kuo TM and Kenty MM (1997) Seed protein and its relationship to soluble sugars in soybean. Crop Science 37: 770-773.

Hymowitz T, Collins Fl, Panczner J and Walker WM (1972) Relationship between the content of oil, protein, and sugar in soybean seed. Agronomy Journal 64: 613-616.

Hyten DL, Pantalone VR, Sams CE, Saxton AM, Landau-Ellis D, Stefaniak TR and Schmidt TE (2004) Seed quality QTL in a prominent soybean population. Theoretical and Applied Genetics 109: 552-561.

Jaureguy LM, Chen P and Scaboo AM (2011) Heritability and correlations among food-grade traits in soybean. Plant Breeding 130: 647-652.

Jiang GL, Chen P. Zhang J, Florez-Palacios L, Zeng A, Wang X, Bowen RA, Miller A and Berry H (2018) Genetic analysis of sugar composition and its relationship with protein, oil, and fiber in soybean. Crop Science 58: 1-9.

Kim HK, Kang ST and Oh KW (2006) Mapping of putative quantitative trait loci controlling the total oligosaccharide and sucrose content of Glycine max seeds. Journal of Plant Research 119: 533-538.

Kim WJ, Smith CJB and Nakayama TOM (1973) Removal of oligosaccharides from soybeans. LWT Lebensmittel Wissensch Technologie 6: 201204.

Ku S, Wei LS, Steimberg MP, Nelson Al and Hymowitz T (1976) Extraction of oligosaccharides during cook of whole soybean. Journal Food Science 41: 361-364. 
Leske KL, Akavanichan O, Cheng TK and Coon CN (1991) Effect of ethanol extraction nitrogen-corrected true metabolizable energy for soybean meal with broilers and roosters. Poultry Science 70: 892-895.

Li YS, Du M, Zhang QY, Wang GH, Hashemi M and Liu XB (2012) Greater differences exist in seed protein, oil, total soluble sugar and sucrose content of vegetable soybean genotypes ['Glycine $\max ^{\prime}(\mathrm{L}$.) Merrill] in Northeast China. Australian Journal of Crop Science 6: 1681-1686.

Liener IE (1994) Implications of antinutritional components in soybean foods. Critical Reviews in Food Science \& Nutrition 34: 31-67.

Liew M, Pryor R, Palais R, Meadows C, Erali M, Lyon E and Wittwer C (2004) Genotyping of single-nucleotide polymorphisms by high-resolution melting of small amplicons. Clinical Chemistry 50: 1156-1164.

Mansur LM, Lark KG, Kross H and Oliveira A (1993) Interval mapping of quantitative trait loci for reproductive, morphological, and seed traits of soybean (Glycine max L.). Theoretical and Applied Genetics 86: 907-913.

Matei G, Woyann LG, Meneguzzi C, Todeschini MH, Trevisan DM, Rosa $A C$ and Benin G (2017) Profiling and genotype $x$ environment interactions of seed sugar contents in Brazilian soybean genotypes. Eyphytica 213: 203.

Mital BK and Steinkraus KH (1975) Utilization of oligosaccharides by lactic acid bacteria during fermentation of soy milk. Journal Food Science 40: 114-118.

Mughal AH, Mughloo JA, Mir AA and Wani MS (2015) Oil content variability and genetic divergence in half-sib families of Prunus armeniaca $\mathrm{L}$. in Kashmir Valley India. African Journal of Agricultural Research 10: 1693-1701.

Neus JD, Fehr WR and Schnebly SR (2005) Agronomic and seed characteristics of soybean with reduced raffinose and stachyose. Crop Science 45: 589-592.

Omosaiye O, Cheryan M and Mathews ME (1978) Removal of oligosaccharides from soybean water extract by ultrafiltration. Journal of Food Science 43: 354-360.

Parsons CM, Zhang Y and Arabat M (2000) Nutritional evaluation of soybean meals varying in oligosaccharide content. Poultry Science 79: 1127-1131.

Paul MJ and Foyer CH (2001) Sink regulation of photosynthesis. Journal of Experimental Botany 52: 1383-1400.

Pham AT, Lee JD, Shannon JG and Bilyeu KD (2011) A novel FAD2-1 A allele in a soybean plant introduction offers an alternate means to produce soybean seed oil with $85 \%$ oleic acid content. Theoretical and Applied Genetics 123: 793-802.
Pham AT, Shannon JG and Bilyeu KD (2012) Combinations of mutant FAD2 and FAD3 genes to produce high oleic acid and low linolenic acid soybean oil. Theoretical and Applied Genetics 125: 503-515.

Qiu D, Vuong T, Valliyodan B, Shi H, Guo B, Shannon JG and Nguyen HT (2015) Identification and characterization of a stachyose synthase gene controlling reduced stachyose content in soybean. Theoretical and Applied Genetics 128: 2167-2176.

Reddy KR, Patro H, Lokhande S, Bellaloui N and Gao W (2016) Ultraviolet-B Radiation Alters Soybean Growth and Seed Quality. Food and Nutrition Sciences 7: 55-66.

Sato T, Schoote MV, Wagentristil H and Vollmann J (2014) Effects of divergent selection for seed protein content in high-protein vs. food-grade populations of early maturity soybean. Plant Breeding 133: 74-79.

Simko I (2016) High-resolution DNA melting analysis in plant research. Trends in Plant Science 21: 528-537.

Skoneczka JA, Maroof MAS, Shang C and Rus GR (2009) Identification of candidate gene mutation associated with low stachyose phenotype in soybean line PI200508. Crop Science 49: 247-255.

Suarez FL, Springfield J, Furne FK, Lohrmann TT, Kerr PS and Levitt MD (1999) Gas production in humans ingesting a soybean flour derived from beans naturally low in oligosaccharides. The American Journal of Clinical Nutrition 69: 135-139.

Teixeira Al, Ribeiro LF, Rezende ST, Barros EG and Moreira MA (2012) Development of a method to quantify sucrose in soybean grains. Food Chemistry 130: 1134-1136.

Tyagi SD and Khan MH (2010) Genetic divergence in lentil. African Crop Science Journal 18: 69-74.

Wang Y, Chen P and Zhang B (2014) Quantitative trait loci analysis of soluble sugar contents in soybean. Plant Breeding 133: 493-498.

Wilcox JR and Shibles RM (2001) Interrelationships among seed quality attributes in soybean. Crop Science 41: 11-14.

Wu SB, Wirthensohn MG, Hunt P, Gibson JP and Sedgley M (2008) High resolution melting analysis of almond SNPs derived from ESTs. Theoretical and Applied Genetics 118: 1-14.

Yang K, Ko JM, Ha TJ, Lee YH, Baek IY, Yang TJ and Nou IS (2014) Development of molecular markers for low raffinose and stachyose in korean soybean cultivars. Plant Breeding and Biotechnology 2: 151-157.

Zeng A, Chen P, Zhang B, Orazaly M, Florez-Palacios L and Brye KR (2015) Identification and confirmation of quantitative trait loci for stachyose content in soybean seed. Plant Breeding 134: 178-185.

(c) $\mathrm{EY}$ This is an Open Access article distributed under the terms of the Creative Commons Attribution License, which permits unrestricted use, distribution, and reproduction in any medium, provided the original work is properly cited. 